\title{
Effect of Sexual Knowledge and Attitude, Exposure to Electronic Media Pornography, Peer Group, and Family Intimacy, on Sexual Behaviors among Adolescents in Surakarta
}

\author{
Yeni Wardhani'), Didik Tamtomo²), Argyo Demartoto3) \\ ${ }^{1)}$ Masters Program in Public Health, Universitas Sebelas Maret \\ 2)Faculty of Medicine, Universitas Sebelas Maret \\ 3)Faculty of Social and Political Sciences, Universitas Sebelas Maret
}

\begin{abstract}
Background: Globalization has tremendous impact on adolescent behaviors, including sexual behavior. Sexual behaviors that exceed socially accepted norms may result in undesireable impact adolescent health. Many factors can affect the sexual behavior of adolescents, both from within and from outside the adolescent self. This study aimed to investigate the effect of sexual knowledge and attitude, exposure to electronic media pornography, peer group, and family intimacy, on sexual behaviors among adolescents.

Subjects and Method: This was an analytic observational study using cross-sectional design. The study was conducted at SMA Negeri Kota Surakarta, Central Java, from March to April 2017. A sample of 100 students were selected for this study by multi-stage sampling. The dependent variable was sexual behaviour. The independent variables were sexual knowledge, attitude toward sex, exposure to electronic pornography, peer group, and family intimacy. The data were collected by a set of pre-tested questionnaire. Path analysis was employed for data analysis.

Results: Adolescent sexual behavior was affected by sexual knowledge $(b=0.16 ; S E=0.05$; $\mathrm{p}=0.006)$, attitude toward sex $(\mathrm{b}=0.18 ; \mathrm{SE}=0.06 ; \mathrm{p}=0.005)$, exposure to electronic pornography $(\mathrm{b}=-0.13 ; \mathrm{SE}=0.05 ; \mathrm{p}=0.026)$, peer group $(\mathrm{b}=0.06 ; \mathrm{SE}=0.03 ; \mathrm{p}=0.042)$, and family intimacy $(\mathrm{b}=0.07 ; \mathrm{SE}=0.03 ; \mathrm{p}=0.038)$. Sexual knowledge was affected by exposure to electronic pornography $(b=-0.20 ; \mathrm{SE}=0.09 ; \mathrm{p}=0.037)$, and peer group $(\mathrm{b}=0.14 ; \mathrm{SE}=0.05 ; \mathrm{p}=0.005)$. Attitude toward sex was affected by exposure to electronic pornography $(b=-0.21 ; \mathrm{SE}=0.08 ; \mathrm{p}=0.013)$, sexual knowledge $(b=0.14 ; \mathrm{SE}=0.08 ; \mathrm{p}=0.110)$, and group $(\mathrm{b}=0.12 ; \mathrm{SE}=0.05 ; \mathrm{p}=0.009)$.

Conclusion: Sexual behavior of adolescents is directly affected by their sexual knowledge, attitude toward sex, exposure to electronic pornography, peer group, and family intimacy.
\end{abstract}

Keywords: sexual behavior, exposure to electronic pornography, PRECEDE PROCEED model, path analysis

\section{Correspondence:}

Yeni Wardhani. Masters Program in Public Health, Universitas Sebelas Maret. Jl. Ir. Sutami 36A, Surakarta, Central Java, 57126. Email: ynwardhani@gmail.com. Mobile: +6285244390776.

\section{BACKGROUND}

Adolescence is a phase of development between childhood and adulthood, lasting until the age of 21 years. Psychologically, adolescence is a period of physical and psychological transition from childhood to adulthood where they become unstable and easily influenced by the surrounding environment (Karyadi, 2008 and Hurlock,
2011). Changes that occur will provide a strong impetus for adolescent behavior that is very diverse (Clemen et al., 2002).

The globalization brings the influence of communication and information that is so fast and unhindered that it can accelerate changes in adolescent deviant behavior such as sexual behavior (Stoebenau et al., 2013). Unhealthy sexual behavior 
among teenagers (especially unmarried teenagers) currently tends to increase in some countries.

Adegoke and Anthony (2013) showed that adolescents in Metropolis, Nigeria had their first sexual intercourse between the ages of 12-18 years. The average age of first sexual intercourse in boys is 13.7 years and age 14.3 years for girls. A total of $21 \%$ of teens is reported being sexually active.

According to a PKBI Central Java (2012) survey of adolescents aged 18-24 years, there were 1,624 adolescents (75.2\%) from 2,159 adolescents having risky sexual behavior. Teenagers who are dating also do kissing, cheating, petting (touching and massaging the area of sexual stimulation), even having sex outside of marriage.

The results of a survey by the Youth Information and Services Center (PILAR) of the Indonesian Family Planning Association (PKBI) in Central Java (2012), with 1,355 study subjects who were high school and vocational high school students, it revealed 392 students or $28.92 \%$ agreed to have sex before marriage. In addition to attitudes toward premarital sex, it also revealed the dating style of 170 students (12.54\%) of teenagers which is not good. Teenagers undergo a relationship with the existence of an act of harassing a partner, physical or psychological abuse, and not respecting a partner.

Sexual behavior in adolescents who transcend reasonableness has a big impact both on the teenagers themselves and on their future partners. Sexual behavior carried out by teenagers with their partners ranging from lip kissing to sexual intercourse is risky sexual behavior, which has an impact on increasing sexual problems such as Unwanted Pregnancy (KTD), married by accident, abortion, venereal disease Sexually Transmitted Infections (STI) and Human Immunodefiency Virus /
Acquired Immuno Deficiency Syndrome (HIV/AIDS) (Sarwono, 2014).

Adolescent sexual behavior is a multidimensional problem that is influenced by various factors both inside and outside of adolescents. Stoebenau et al., (2013) stated that the factors that influence adolescent sexual behavior are age, gender, family role, peer influence, amount of allowance, lack of knowledge, exposure to advertising, understanding level of religion, source of information, lifestyle, culture and conditions of economic uncertainty.

Human behavior, especially health behaviors, can be analyzed with the PRECEDE-PROCEED theory which is proposed by Green and Kreuter and is known as behavior theory. PRECEDE is a process of needs assessment, determining needs and contributing to needs. PROCED is an ecological diagnosis in the form of policies, regulations and organizational constructs in education and environmental development (Green and Terry, 2015).

Lawrence Green (1980) explained that the behavior is determined from predisposing factors (or factors within the individual this includes knowledge, attitudes, beliefs, values and norms adopted), supporting factors (health facilities, affordability of health facilities, and health regulations. Factors which strengthen are (factors that can be a barrier to behavior change) (Sulaeman, 2014).

\footnotetext{
SUBJECTS AND METHOD

\section{Study design}

This was an analytic observational study with a cross sectional design. The study was conducted at 1, 5, and 6 senior high scholls in Surakarta, from March to April 2017.

\section{Population and sample}

The population in this study was all students of class XI of senior High Schools in Surakarta. The sampling technique used
} 
was multistage sampling, which is cluster sampling technique to determine schools and proportional random sampling techniques to determine the proportion of study subjects. The study subject was 100 adolescents.

\section{Study variables}

The dependent variable was sexual behavior. The independent variables were knowledge about sexuality, attitude toward sexuality, exposure to pornography in electronic media, peer, and family intimacy.

\section{Operational definition of variables}

Knowledge of sexuality was defined as what people know about the sexuality as a physiological and psychological expression of individuals, both men and women, which is related to sexual activity that includes responsible biological, psychological, social, behavioral and cultural dimensions of personal life and social in accordance with existing norms in society and religion.

Attitude toward sexuality was anything that shows a reaction or response about an individual's sexual drive or desire as a physiological and psychological expression of an individual, both men and women related to sexual activity including biological, psychological, social, behavioral and cultural dimensions.

Exposure to pornography in electronic media was defined as anything that shows linkages to channels or media used to provide information that can arouse lust in audio, visual or audiovisual form. Peers are individuals or groups of peers whose activities or actions can cause positive influence and are imitated and carried out by research subjects.

Family intimacy was defined as anything that shows the closeness of the relationship between family members which is manifested by mutual trust, openness and mutual sharing between family members, especially parents and adolescents related to sexuality problems that affect adolescent sexual behavior.

\section{Reliability Test}

Based on the results of item-total correlation reliability test, it was found that in measuring the variables of knowledge about sexuality, attitudes toward sexuality, exposure to pornography in electronic media, peers, family intimacy, and adolescent sexual behavior, with item correlation $>0.20$ and Alpha Cronbach $\geq 0.70$, so all question items are declared reliable.

\section{Data Analysis}

Univariate quantitative data analysis was performed to display characteristic data and descriptive research variables, bivariate analysis was carried out to analyze the effect of exogenous variables on endogenous variables using the Chi-Square test. Path analysis was conducted to analyze the direct and indirect effects of exogenous variables on the endogenous variables through intermediate variables.

\section{RESULTS}

The characteristics of studys subjects were 100 adolescents from 3 schools according to age, sex, paternal work and maternal work shown in Table 1.

Table 1 shows that out of 100 adolescents, male subjects were $26 \%$ and female subjects were $26 \%$. Teenagers age 16 years (6o\%) and aged 17 years (40\%). Paternal education mostly diploma/ undergraduate (57\%), high school/ vocational school (34\%), junior high school (6\%) and elementary school graduates (3\%). Maternal education is mostly diploma / undergraduate education for about $43 \%$, high school (45\%), junior high school education (7\%) and elementary school education (5\%). 
Wardhani et al./ Effect of Sexual Knowledge and Attitude, Exposure to Electronic

Table 1. The characteristics of study subjects

\begin{tabular}{llcc}
\hline \multicolumn{1}{c}{ Characteristics } & \multicolumn{1}{c}{ Category } & n & \% \\
\hline Gender & Male & 26 & 26.0 \\
Age (years) & Female & 74 & 74.0 \\
Parental education & 60 & 60.0 \\
& 16 & 40 & 40.0 \\
& Primary school & 3 & 3.0 \\
& Junior high school & 6 & 6.0 \\
& Senior high school & 34 & 34.0 \\
& Diploma/Bachelor & 57 & 57.0 \\
& Primary school & 5 & 5.0 \\
& Junior high school & 7 & 7.0 \\
& Senior high school & 45 & 45.0 \\
& Diploma/Bachelor & 43 & 43.0 \\
\hline
\end{tabular}

Descriptive results of continuous continuous statistics in the form of knowledge about sexuality, attitudes toward sexuality, exposure to pornography in electronic media, peers, family intimacy and adolescent sexual behavior can be seen in Table 2.

Table 2. Univariate analysis of study variables

\begin{tabular}{lccccc}
\hline \multicolumn{1}{c}{ Variable } & n & Mean & SD & Min. & Max. \\
\hline Knowledge about sexuality & 100 & 17.43 & 1.35 & 12 & 20 \\
Attitude towards sexuality & 100 & 40.79 & 1.24 & 39 & 43 \\
Exposure to pornography in electronic media & 100 & 21.46 & 1.32 & 19 & 24 \\
Peer & 100 & 19.94 & 2.55 & 15 & 27 \\
Family Intimacy & 100 & 28.34 & 2.19 & 16 & 33 \\
Adolescent sexual behavior & 100 & 9.40 & 0.94 & 7 & 11 \\
\hline
\end{tabular}

Table 2 shows that each variable has a relatively small amount of data. Mean describes the average value, while the standard deviation (SD) value describes how far the data varies. A small standard deviation is an indication that the data is representative.

Table 3. Bivariate analysis of factors that influence adolescent sexual behavior

\begin{tabular}{lcc}
\hline \multicolumn{1}{c}{ Variable } & $\mathbf{r}$ & P \\
\hline Knowledge of sexuality & 0.40 & $<0.001$ \\
Attitude towards sexuality & 0.44 & $<0.001$ \\
Exposure to pornography in electronic media & -0.27 & 0.005 \\
Peer & 0.38 & $<0.001$ \\
Family intimacy & 0.33 & 0.001 \\
\hline
\end{tabular}

Table 3 shows that knowledge about sexuality $(\mathrm{r}=0.40 ; \mathrm{p}<0.001)$, attitudes toward sexuality $(\mathrm{r}=0.44 ; \mathrm{p}<0.001)$, peers $(\mathrm{r}=0.38, \mathrm{p}<0.001)$, family intimacy $(\mathrm{r}=$ $0.33, p=0.001$ ) has a positive influence on adolescent sexual behavior. Pornographic representation in electronic media $(r=-$
0.27; $\mathrm{p}=0.005$ ) has a negative influence on adolescent sexual behavior. The higher the knowledge about sexuality, the better the sexual behavior. The better the attitude towards sexuality, the better the sexual behavior. The higher exposure to pornography, the worse sexual behavior. The 
more positive the influence of peers, the better sexual behavior. The stronger the family intimacy, the better the sexual behavior.

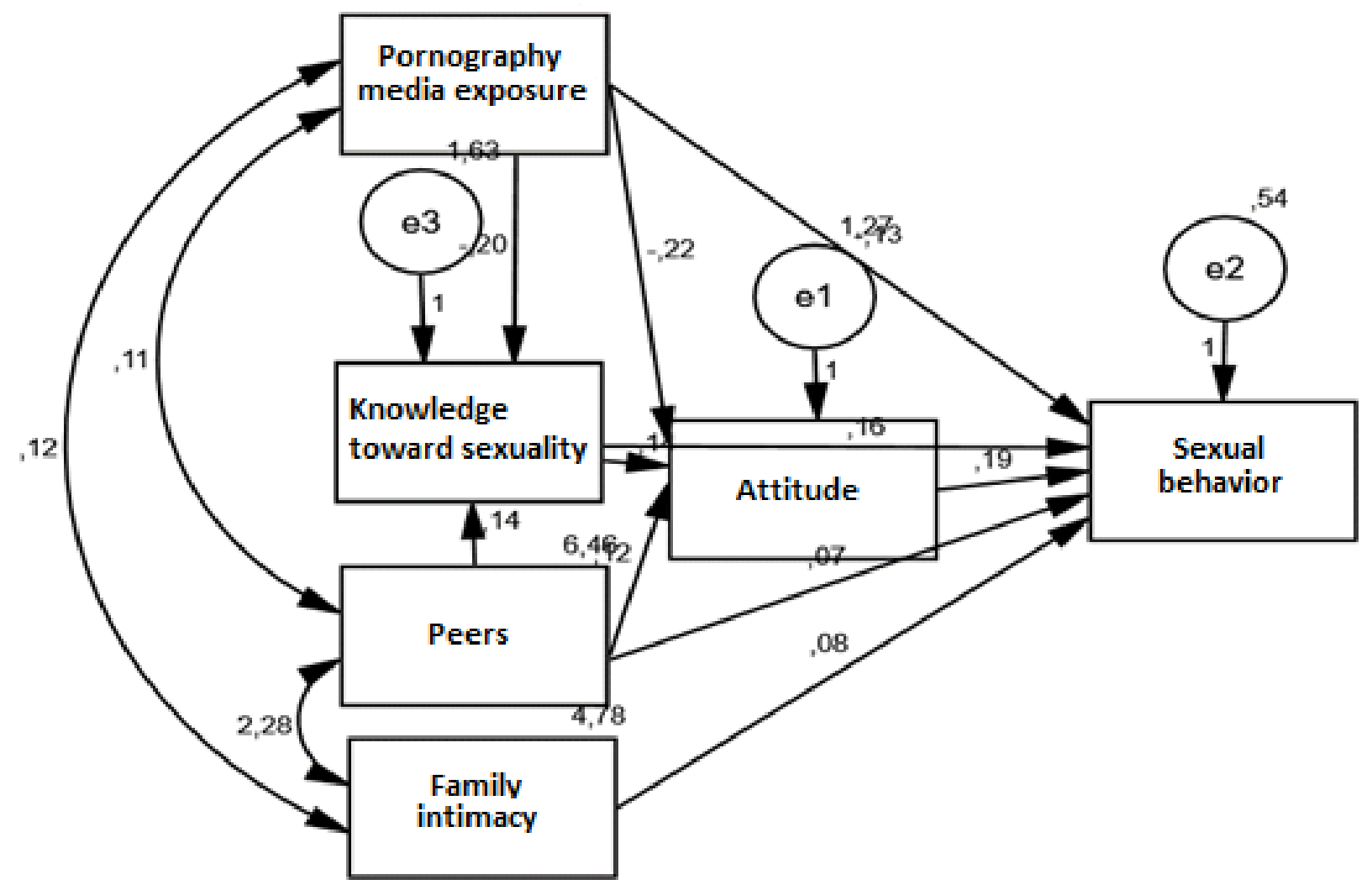

Figure 1. Structural Model of Path Analysis

Figure 1 showed the structural model after estimation by using IBM SPSS AMOS 20, so that the score could be obtained as shown in the figure. Indicators that showed the suitability of the path analysis model, as in Table 5, also showed the goodness of fit measure that the CMIN fit index result was 1.83 , with the score of $\mathrm{p}=0.399>0.05$; $\mathrm{NFI}=0.98>0.90 ; \mathrm{CFI}=1.00>0.90 ; \mathrm{RMSEA}$ $<0.001$ (<0.08) which mean that the empirical model fulfilled the criteria specified and it was in accordance with the empirical data.

Through Table 4, it can be seen that adolescent sexual behavior was directly influenced by knowledge about sexuality, attitudes toward sexuality, exposure to pornography in electronic media, peer groups, and family intimacy.
Every enhancement of one unit of sexual knowledge would increase good sexual behavior in adolescents by 0.16 unit $(b=0.16 ; \mathrm{SE}=0.05 ; \mathrm{p}=0.006)$.

Every enhancement of one unit of attitude toward sexuality would increase good sexual behavior in adolescents by 0.18 unit $(b=0.18 ; \mathrm{SE}=0.06 ; \mathrm{p}=0.005)$.

Every enhancement of one unit of peer group would increase good sexual behavior in adolescents by 0.06 unit $(b=$ $0.06, \mathrm{SE}=0.03, \mathrm{p}=0.042$ ).

Every enhancement of one unit of family intimacy would increase good sexual behavior in adolescents by 0.07 unit ( $b=0.07$; $\mathrm{SE}=0.03 ; \mathrm{p}=0.038$ ).

Every enhancement of one unit of sexual knowledge was affected by decreased exposure to pornography in electronic 
media by -0.20 unit $(b=-0.20 ; \mathrm{SE}=0.09$; $\mathrm{p}=0.037)$.

Sexual knowledge was affected by peer group. Every enhancement of one unit of peer group would increase sexual knowledge by 0.14 unit $(b=0.14, \mathrm{SE}=0.05, \mathrm{p}=$ 0.005).

Attitude toward sexuality was affected by exposure to pornography in electronic media. Every enhancement of one unit of attitude toward sexuality was affected by decreased exposure to pornography in electronic media by -0.21 unit $(b=-0.21$, $\mathrm{SE}=0.08, \mathrm{p}=0.013$ ).

Attitude toward sexuality was affected by sexual knowledge. Every enhancement of one unit of sexual knowledge would increase the attitudes toward sexuality by 0.14 unit $(b=0.14, S E=0.08, p=0.110)$.

Attitude toward sexuality was affected by peer group. Every enhancement of one unit of peer group would increase the attitude toward sexuality by 0.12 unit $(b=$ $0.12, \mathrm{SE}=0.04, \mathrm{p}=0.009$ ).

Table 4. The Results of Path Analysis

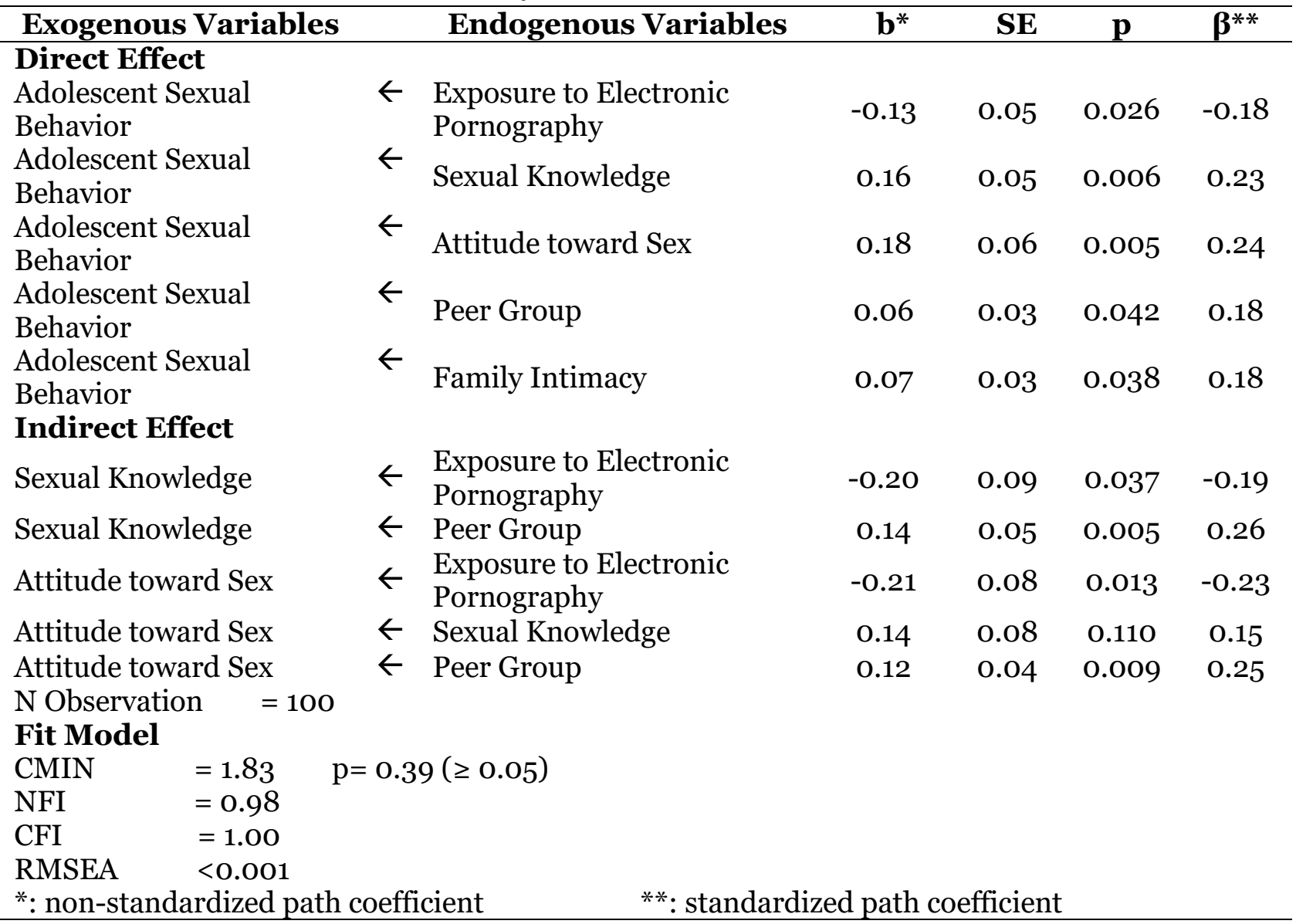

\section{DISCUSSIONS}

\section{The effect of sexual knowledge on adolescents' sexual behaviour}

There was a direct and positive relationship between sexual knowledge and adolescents' sexual behaviour which was statistically significant. The result of analysis also showed that there was a direct and negative relationship between sexual knowledge through pornography exposure in electronic, and there was a direct and positive relationship between sexual knowledge through peer group on adolescents' sexual behaviour.

The result of this study was in line with a study done by Bakti (2012) which 
Journal of Health Promotion and Behavior (2017), 2(2): 140-149

https://doi.org/10.26911/thejhpb.2016.02.02.04

stated that adolescents who have knowledge about the functions of sexuality and good reproductive health tend to avoid deviant sexual behavior or unhealthy sexual behavior in adolescents.

Wusu (2013) stated that the amount of information about sexual health implied the enhancement of adolescent's sexual health knowledge so that adolescents avoided risky sexual health behaviors.

The result of this study was also in line with a study done by Keswa and Notole (2014) which stated that there was a relationship between pornography exposure and adolescent's sexual knowledge which also affected by peer group. The adolescents who often exposed to pornographic media could affect imbalances in psychological, emotional, and cognitive development. This imbalance in cognitive development also affected adolescents in understanding the information obtained as a basis for knowledge about sexuality. Understanding wrong information lead to poor knowledge about sex and could cause the adolescent to imagine pornography so that they would try and engage in unhealthy sexual behaviour.

\section{The effect of attitude toward sexuality on adolescents' sexual behaviour}

There was a direct and positive relationship between attitude toward sexuality and adolescents' sexual behaviour which was statistically significant. The result of analysis also showed that there was a direct and positive relationship between attitude toward sexuality through sexual knowledge and peer group on adolescent's sexual behaviour which was statistically significant. Adolescents who have good knowledge about sexuality would have good attitude toward sexuality.

There was a direct and negative relationship between attitude toward sexuality through exposure to electronic pornography and adolescent's sexual behaviour. Attitude was one of the individual factors that affect sexual behavior. The more often the adolescents were exposed to pornographic media, the more permissive their sexual attitude. If adolescents have a permissive attitude toward sexuality, then the potential for unhealthy sexual behavior was quite large (Courvile and Rojas, 2009 in Owens et al., 2012). Attitude was a closed response whose the manifestations cannot be seen directly and predisposed to behavior (Nursal, 2007).

There were many factors that affected adolescents' sexual attitudes and behavior. Adolescence was a time when someone looked for identity, defined, and builded his/her sexual profile. Influences from the environment such as peer environment, information media, family, and sociocultural background could be an obstacle and even became a supporting factor for adolescents' attitudes and sexual behavior (Bae and Dong, 2015).

\section{The effect of exposure to electronic pornography on adolescents' sexual behaviour}

There was a direct and negative relationship between exposure to electronic pornography and adolescents' sexual behaviour which was statistically significant. Adolescent's interest in pornographic material on the internet was related to the transition period experienced by the adolescents. Adolescents experienced various kinds of changes, namely the physical, sexual, emotional, religious, moral, social, and intellectual aspects (Hurlock, 2011).

The existence of the dissemination of information media and sexual stimulation through mass media, especially electronic media, namely the presence of sophisticated technology such as the internet, digital magazines, television, and videos, 
made the adolescents tend to want to know, try, and imitate what they have seen and heard. Print and electronic media were the most widely used media for disseminating pornography. Hormonal development in adolescents was driven by exposure to electronic media that brought the curiosity and provoked the desire to experiment in sexual activity.

Changes in the sexual aspect were related to the maturation of the pituitary gland which stimulated the release of hormones that affected the reproductive organs which increased child's sexual drive. Adolescents became more aware of things related to sex and try to find more information about sex, including information about sex that was so easy to get from the Internet. Adolescent became one of the segments that were vulnerable to the existence of pornography, especially pornographic sites. Furthermore, Hurlock's also mentioned that adolescents were more interested in sex material in the form of pornography compared to sex material in the form of education (Hurlock, 2011).

\section{The effect of peer group on adolescents' sexual behaviour}

There was a direct and positive relationship between peer group and adolescents' sexual behavior which was statistically significant. It can be said that adolescents who have good peer groups or have good knowledge and attitudes about sexuality could have a good impact on their sexual behavior. But on the contrary, if adolescents have groups of peers who have bad knowledge and attitudes about sexuality, it could improve bad or unhealthy sexual behavior.

The result of this study was in line with a study done by Qomarasari (2015) which stated that peer group has a strong effect on adolescents. The existence of peers has a positive effect on the values of adolescent society in the social environment, therefore, a peer group was able to provide motivation (peer motivation), support and, opportunities to positively actualized themselves to all its members.

\section{The effect of family intimacy on adolescents' sexual behaviour}

There was a direct and positive relationship between family intimacy and adolescents' sexual behavior which was statistically significant. The family has an important role in the development of the child's personality because family was the first place for the child to get experience and education. Good communication between parents and children would ease the parents to monitor children's activities and environment, always get involved in activities, and improve communication with their children related to reducing the risk of sexual behavior in adolescents and it was better for religious families.

Good communication between parents and children would ease the parents to instill a strong self foundation in children, for example by providing religious education and information about reproductive health as early as possible to minimize the occurrence of unhealthy adolescent's sexual behavior.

Good parenting and communication in the family has an important role in the development of the child's personality. Because in the family, the children got their first experience and education, so it needed to instill a strong self-foundation in children so that they were not easily affected by negative things from the environment outside the family. The role of parents has a huge effect on adolescents. Busy parents, poor parenting quality, and parental divorce could caused the adolescents to experience depression, confusion, and emotional inadequacy that prevent them from being responsive to adolescent needs, and it caused the adolescents to easily fall into 
Journal of Health Promotion and Behavior (2017), 2(2): 140-149

https://doi.org/10.26911/thejhpb.2016.02.02.04

deviant behaviors such as sexual behavior. (Santrock, 2011).

\begin{tabular}{l}
\hline REFERENCES \\
\hline Adegoke AA (2013). Sexual Behaviour \\
Practices of Secondary School Adoles- \\
cents in Ibadan Metropolis, South \\
West Nigeria Adegoke, Adekunle \\
Anthony. Ife PsychologIA, 21(2). \\
Bae YS, Kim DH (2015). A Comparison of \\
the Sexual Knowledge, Attitudes, and \\
Behaviors of Korean College Students \\
Studying in Korea and in the United \\
States. Open Journal of Nursing, \\
5(11): 1053-1062. Doi: 10.4236/ojn.- \\
2015.511112
\end{tabular}

Bakti M (2012). Hubungan Pengetahuan Kesehatan Reproduksi Remaja dan Keintiman Keluarga dengan Sikap Seksual Pranikah di SMAN 1 Sukoharjo. Tesis. Surakarta: Pascasarjana Kedokteran Keluarga. Universitas Sebelas Maret Surakarta.

Clemen S, McGuire SL, Eigsti DG (2002). Comprehensive Community Health Nursing: Family, Aggregate, \& Community Practice (6rd Ed). St. Louis: Mosby, Inc Journal.

Hurlock EB (2011). Psikologi Perkembangan. Jakarta: Erlangga.

Karyadi (2008). Hubungan Pola Asuh Keluarga Terhadap Perilaku Merokok pada Remaja Laki-laki di Desa Kenteng Kecamatan Nogosari Kabupaten Boyolali Tahun 2007. Skripsi. Fakultas Ilmu Kesehatan Universitas Muhammadiyah Surakarta.

Keswa JG, Notole M (2014). The Impact of Pornography on Adolescent Males' Sexual Behaviour in the Eastern Cape, South Africa. A Qualitative Study. Mediterranean Journal of Social Sciences, 5(20): 2039-9340. Doi: 10.5901/mjss.2014.v5n2op2831.
Nursal DGA (2007). Faktor-faktor yang Berhubungan dengan Perilaku Seksual. Jurnal Kesehatan Masyarakat. 2(2).

Owens EW, Behun RJ, Manning JC, Reid RC (2012). The Impact of Internet Pornography on Adolescents: A Review of The Research. Sexual Addiction \& Compulsivity Journal, 19:99122. Doi: 10.1080/10720162.2012.660431.

Perkumpulan Keluarga Berencana Indonesia (PKBI) Propinsi Jawa Tengah (2012). Perilaku Seks Kalangan Pelajar di Semarang. Semarang: Pusat Informasi dan Layanan Remaja (Pilar) PKBI.

Qomarasari D (2015). Hubungan Peran Keluarga, Sekolah, Teman Sebaya, Pendapatan Keluarga, Media Informasi dan Norma Agama dengan Perilaku Seksual Remaja SMA di Surakarta. Tesis. Surakarta: Program Studi Ilmu Kesehatan Masyarakat. Program Pascasarjana. Universitas Sebelas Maret Surakarta.

Santrock JW (2012). Remaja. Jakarta: Erlangga.

Sarwono SW (2014). Psikologi Remaja. Bandung: PT Bumi Siliwangi.

Stoebenau K, Nair RC, Rambeloson V, Rakotoarison PG, Razafintsalama V, Labonté R (2013). Consuming Sex: The Association Between Modern Goods, Lifestyles And Sexual Behaviour Among Youth In Madagascar. Globalization and Health, 9:13. doi: 10.1186/1744-8603-9-13.

Sulaeman ES (2014). Promosi Kesehatan. Surakarta: UNS Press.

Green L, Terry PE (2015). What's Past is Prologue: Views from Dr. Lawrence Green. Am J Health Promot. 29(3): TAHP2-8. 
Wardhani et al./ Effect of Sexual Knowledge and Attitude, Exposure to Electronic

Wusu O (2013). Exposure to Media Content and Sexual Health Behaviour among Adolescents in Lagos Metropolis,
Nigeria. African Journal of Reproductive Health, 17(2): 157-68. 